\title{
The Reason for Learner-Centered Approach
}

An active student is a busy learner. Interacting with learning materials gives the learner an environment where new knowledge is absorbed faster and experientially. This method is the opposite of instructor centered approaches where the teacher is the sole source of information.

Below I preface why student involvement has an award over the teacher centered approach.

The knowledge base. What we already know determines what new information we attend to, how we organize and represent new information, and how we filter new experiences, and even what we determine to be important or relevant (Alexander \& Murphy, 2000).

Strategic processing and executive control. Successful students keep themselves involved in their own learning, monitor their thinking, think about their learning, and assume responsibility for their own learning (Lambert \& McCombs, 2000).

Motivation and affect. The benefits of learner-centered education include increased motivation for learning and greater satisfaction with school; both of these outcomes lead to greater achievement (Johnson, 1991; Slavin, 1990). Research shows that personal involvement, intrinsic motivation, personal commitment, confidence in one's abilities to succeed, and a perception of control over learning lead to more learning and higher achievement in school. (Alexander \& Murphy, 2000).

Development and individual differences. Depending on the context or task, changes in how people think, believe, or behave are dependent on a combination of one's inherited abilities, stages of development, individual differences, capabilities, experiences, and environmental conditions. (Alexander \& Murphy, 2000).
Situation or context. Theories of learning that highlight the roles of active engagement and social interaction in the students' own construction of knowledge (Kafai \& Resnick, 1996; Piaget, 1963; Vygotsky, 1978) strongly support learner-centered approach. Learning is a social process. Many environmental factors including how the instructor teaches, and how actively engaged the student is in the learning process positively or negatively influence how much and what students learn (Lambert \& McCombs, 2000).

This special issue presents articles on teaching/learning approaches which, if utilized appropriately, can yield encouraging results in the learning-teaching process.

\section{References}

[1] Alexander, P., \& Murphy, P. (2000). The research base for APA's leaner-centered psychological principles. In N. Lambert, \& B. McCombs (Eds.), How students learn (pp. 25-60). Washington, D.D.: American Psychological Association.

[2] Lambert, N., \& McCombs, B. (2000). Introduction: Learnercentered schools and classrooms as a direction for school reform. In N. Lambert, \& B. McCombs (Eds.), How students learn (pp. 115). Washington, D.C.: American Psychological Association.

[3] Johnson, W. D. (1991). Student-student interaction: The neglected variable in education. Educational Research, 10 (1), 5-10.

[4] Kafai, Y., \& Resnick, LM. (1996). Constructionism in practice. Mahwah, New Jersey: Lawrence Erlbaum Associates.

[5] Piaget, J. (1963). Origins of intelligence in children. NY: Norton.

[6] Slavin, R. E. (1990). Cooperative learning theory, research and practice. Needham Heights, MA: Allyn and Bacon.

[7] Vygotsky, L. S. (1978). Mind in society: The development of higher mental process. Cambridge, MA: Harvard University Press. 